\title{
A philosophical assessment of the changing trends of Buddhism in contemporary Vietnam
}

\author{
Tuan Van Chu
}

DOI: 10.18355/XL.2020.13.03.05

\begin{abstract}
Since the beginning of the Doi Moi Renovation in Vietnam, major changes have taken place in religions. Mainstream religions such as Christianity and especially Buddhism have been revitalized and begun to develop rapidly. Based on the results of recent field trips and surveys, the author seeks to generalize the changing trends of Buddhism in contemporary Vietnam and assess these philosophically. The main foci of his analysis are on Buddhist faith, practice, and community. This research illustrates that the remarkable changes in Vietnamese Buddhism in the last 15 years can be seen as a consequence of the economic, political, social renovation, and of innovative efforts by Buddhists themselves.
\end{abstract}

Key words: Changing trends, Buddhism, faith, practice, community, karma

\section{Introduction: The Current Situation of Buddhism in Vietnam}

Up to the present, 16 religions and 43 religious organizations have been recognized as juridical entities by the State of Vietnam. Buddhism has the oldest history of propagation and development in Vietnam compared to other foreign religions. In addition, Buddhism has always accompanied the nation during its numerous struggles for peace and independence. The Buddhist religious doctrine has also been integrated into and becomes an important component of the Vietnamese culture, thus contributed to the creation and preservation of Vietnamese cultural identities. At present, there are around 14 self-identified million Buddhists, and this makes Buddhism the religion with the largest number of followers in comparison to all other religions in Vietnam. Moreover, millions of Vietnamese people who are sympathetic to Buddhism and practice the doctrines in some ways though not calling themselves a Buddhist.

Buddhism is present in all regions of the country and among many different ethnic groups. Yet the majority of followers are the Kinh. Over the last 20 years, Buddhism has attracted followers belonging to minority ethnic groups in the northern mountainous area and in the Central Highlands.

Buddhism was introduced into Vietnam through two paths, from India, and from China. Buddhism propagated from China was the Mahayana school. Meanwhile, Buddhism brought from India was the Theravada school. The Theravada school has great influences in many countries, including Sri Lanka, Myanmar, Thailand, Laos, etc. Therefore, Vietnamese Buddhism has many different denominations, such as Northern Buddhism (Bac tong), Southern Buddhism (Nam tong), and Mendicancy (Khat sy). Although the Mahayana school can be found throughout the country, its followers mostly reside in the North and the Middle and mostly are the Kinh. Theravada is mainly practiced in the South among the Khmer. Mendicancy is popular in the South, the Central Highlands and its followers are mostly the Kinh.

Although the Buddhist schools in Vietnam vary, they mostly belong to the Vietnam Buddhist Sangha (VBS). This state-recognized Buddhist organization unites different schools and denominations and has a complete administrative system from the central to local levels.

In recent years, Vietnamese Buddhism has strong development in many aspects including an increase in the number of followers, dignitaries, monasteries; training courses; a rise of mass media in association with the propaganda of Buddhism; an increase in the scope and frequency of social activities; and the expansion of 
international relations of the VBS. Until present, VBS has organized many key international Buddhist events, including the Vesak Day in 2008, 2014, and 2019 respectively. Vietnam Buddhism has also boosted propagation to Vietnamese diaspora and established Buddhist centers in several countries. Reversely, more and more foreign Buddhist delegations have been invited to Vietnam for propagation, exchanges, and participation in academic conferences, seminars, and inter-faith dialogues.

Recently, international researchers have been much interested in religious changes in Vietnam since Renovation. Religious revival is among the major processes that take place in this modernizing nation. This process can be observed through restoration and promotion of religious festivals, cultic places, ritual practice, and an increase in expenditure for religious purposes (see Malarney, 2002; Taylor, 2004, 2007; Pham, 2009). Religious diversification is another major process that contributes significantly to profound changes in religious life as the Vietnamese seek to widen and deepen their relationship with international communities. Consequently, diversification has been intensified both internally to a religious organization and externally to the whole religious landscape. The society witnesses diverse ways in which religious adherents express religious beliefs, perform rituals and establishment of faith-based associations and groups (see Hoang, 2019).

Interests in religious changes and transformation can be found in many books, journals, and research projects published by domestic researchers. Some typical research themes can be listed such as Transformation of religions, beliefs in Vietnam at present (many authors 2008); Transformation of religions in Vietnam in the impact of globalization (Nguyen, 2010); Changes and development of religions under the influence of globalization over the past ten years (Le, 2010); Transformation of religions and beliefs in the context of Vietnam's international integration (Nguyen Chu, 2014); Transformation of Buddhism in Vietnam and sustainable development, Transformation of Catholicism in Vietnam and sustainable development, Transformation of Protestantism in Vietnam and sustainable development, Transformation of folk religion in Vietnam and sustainable development. Some workshops such as the transformation of religions in the Central Highlands: Current status, policies, and solutions (Institute for Religious Studies, 2013); Religious changes and trends in the Centre of Vietnam: Policy Planning (Institute for Religious Studies, 2017); Transformation of religious life in Vietnam in the context of renovation and international integration (Nguyen, 2017). These works provide various pieces of evidence for multiple-dimensional changes in religious life at both private and public levels. Against this backdrop, I will analyze changing trends in Buddhism in recent decades.

\section{The change in Buddhist demography}

In the last 20 years, Vietnamese Buddhism witnesses a dramatic increase in terms of followers. In 2009, according to the national Census data, the number of Buddhists was about 6,8 million. By 2018, the number of Buddhists has been doubled, with more than 14 million. However, it can be said that there has not been an independent and comprehensive survey of religious demographics in Vietnam. The aforementioned figures are mainly based on the national Census data by the General Statistical Office and the reports by the Government Committee for Religious Affairs - the State management agency for religious activities. The figures provided by the Government Committee for Religious Affairs sometimes did not match with the figures reported by religious organizations. For example, the Government Committee for Religious Affairs reports that the number of Buddhists was more than 14 million, while the Vietnam Buddhist Sangha claimed a much higher number, at around 50 million.

XLinguae, Volume 13 Issue 3, June 2020, ISSN 1337-8384, ISSN 2453-711X 
There was a sharp increase of Buddhists during 2009-2018. According to a report of the Buddhist Sangha of Vietnam, there was an increase of 131,335 Buddhists within 5 years, from 2012 to 2017. Consequently, after 9 years, the number of believers has doubled. It is noteworthy that, along with the rise in quantity, Buddhists have become ever diversified in classification. Three decades ago, Buddhist practitioners were mainly women, elderly people, farmers, businessmen, and small traders. The old saying "young people enjoying staying home, old people enjoy attending Buddhist temple" reflects this pattern. In the past, the Vietnamese tended to be with Buddhist temples when they became old. Currently, there are more Buddhists at a young age, and the proportion of men participating in Buddhist activities has significantly increased. Meanwhile, the percentage of Buddhists who are intellectuals, or government officials have arisen as well.

The abbot of Keo Buddhist temple, a famous ancient Pagoda in Thai Binh province, told us that there had been changes among those who believe in Buddhism. Previously, people who came to the temple were mostly local residents or the lay Buddhists who lived around the pagoda. Then the number of people from other places visited the temple had increased, especially the young. In the past, people who visited the pagoda were mostly old people, retirees, and women. At present, there is a rise among Buddhist practitioners who are young people, intellectuals, and officials. Those who are sympathetic to Buddhism do not only visit Buddhist temples, but they also participate in ritual practices.

Inherently, Buddhism has seen an increase in both the quantity and quality of followers. It seems that the religion's development has gained momentum; thus, the further transformation will take place.

\section{The Change in Faith}

Regarding the change in faith in Buddhism, one should firstly look at the trend of conversion to Buddhism. According to the Institute for Religious Studies' research findings, there are more converts to Buddhism who were previously followers of other religions. The Institute's surveys have discovered that many followers of other religions such as Catholicism, Protestantism, Caodaism, etc. converted to Buddhism. It should be emphasized here that former practitioners of folk religion make up the largest number of converts to Buddhism.

Among the new converts, ethnic minorities account for a large proportion. These people used to follow other religions or their traditional religious beliefs. There were not many ethnic minorities in Vietnam who were converted to Buddhism in the past; only a small number were converted to Catholicism and Protestantism. One of the reasons for the rise in new converts to Buddhism is that VBS has intensified propaganda among ethnic minorities in recent years. This is followed by the construction of many new Buddhist temples in the areas where they live. Further, VBS has been much active in doing charitable works, engaging in educational activities, and provide health care to the public, etc. All these activities have enabled ethnic minorities to understand Buddhism better. According to the Institute for Religious studies' survey results, Buddhist conversion has mainly taken place in the provinces of the Middle and the Central Highlands.

According to a report by the Committee for Religious affairs of Dak Lak province in the Central Highlands, the number of ethnic minorities converted to Buddhism has increased in Buon Ma Thuot city, Cư M'gar district, and Krong Pac district. (Institute for Religious Studies \& the Central Highlands Steering Committee, 2013). In 2009, the Executive Board of VBS organized a Sarana (a joining Buddhism ceremony) for about 3,000 people who are ethnic minorities in Kon Tum (of the Central Highlands). (Institute for Religious Studies \& the Central Highlands Steering Committee. 2013). According to the Sangha, there were 3,750 Buddhists of minor ethnicity in Ninh Thuan and Dak Lak provinces by 2017. 
Conversely, there are Buddhists who have just been converted to Catholicism and Protestantism. (There is no statistic of Catholics, Protestants converting to Buddhism in Vietnam). Based on our fieldwork in the South-western provinces (Tay Nam Bo), a part of the Theravada Buddhist community has been converted to Catholicism and Protestantism. This is a result of the efforts in the evangelization efforts conducted by the Catholics and Protestants (especially Protestantism) among the Khmer community. Also, for changes in livelihoods, some of the Khmers have sought to escape ties with their traditional community. As working away from home, they were approached by missionaries then converted to Catholicism or Protestantism. Some were converted to Protestantism because of receiving help and support at times when they faced illnesses or troubles in daily life.

The following story provides an example. Before Tran N., 47-year-olds, a Khmer, joins Protestantism, he had suffered from muscular dystrophy. Whatever had been done could not help him to get rid of the illness. He then decided to become a Protestant. As he kept making prayers every day, his illness gradually disappeared. He said that he was cured by God's power. He then became a student at the Bible School (These were the results of an in-depth interview with Mr. Tran N. (47-year-old), the Khmer at the Nhon Loc Group, Can Tho City. He said that his wife and children were also following Protestantism. According to the in-depth interview with Pastor of the Baptist Church of Can Tho City, the pastor said that about 10 percent of the Khmer people converted to Protestantism). Regarding the conversion of a part of the Khmers in the Southwest Region to Christianity, Huu Hop Tran showed statistics on the number of the Khmer Catholics and Protestants. (Nguyen et al., 2019) According to his data, by 2015, there were 3,202 Catholics and 2,195 Protestants in the Southwest region. (Tran, 2017: 100,103). Besides, the Khmers have also converted to other religions such as Hoa Hao Buddhism and Caodaism.

Regarding the level of Buddhist doctrinal understanding, through qualitative research and observations, the author found that Buddhists have a better understanding of Buddhist doctrines in comparison to the past. Therefore, the previous common view stating that Vietnamese Buddhists often have little knowledge of Buddhist doctrines is questionable. Results of a survey of 300 Buddhists showed that $92.5 \%$ of the respondents said that they had moderate or deep comprehension about Buddhist doctrine. Among them, those who said that they understood much about Buddhism accounted for $30.4 \%$, and those who had a moderate understanding of Buddhism accounted for the highest proportion with $62.1 \%$. Only $7.5 \%$ of respondents said they understood a little about Buddhism.

The reason for a better understanding of the Buddhist doctrine and precepts is because Buddhists have attended more lecturers, read books, newspapers, magazines, and especially used the Internet for their self-learning. The table below shows that in the past, mainly monks and nuns studied the Buddha's teachings. Today, there are many other forms of studying the Buddha's teachings such as listening to tapes, CDs, radio, television or visiting websites on the Internet, etc. It also reflects the fact that Buddhists today are also quite active in studying doctrine and precepts and do not entirely rely on monks and nuns' teachings. (Chadwin, 2020)

Chart 1: Comparing the study of Buddhist doctrine in the past and at present 


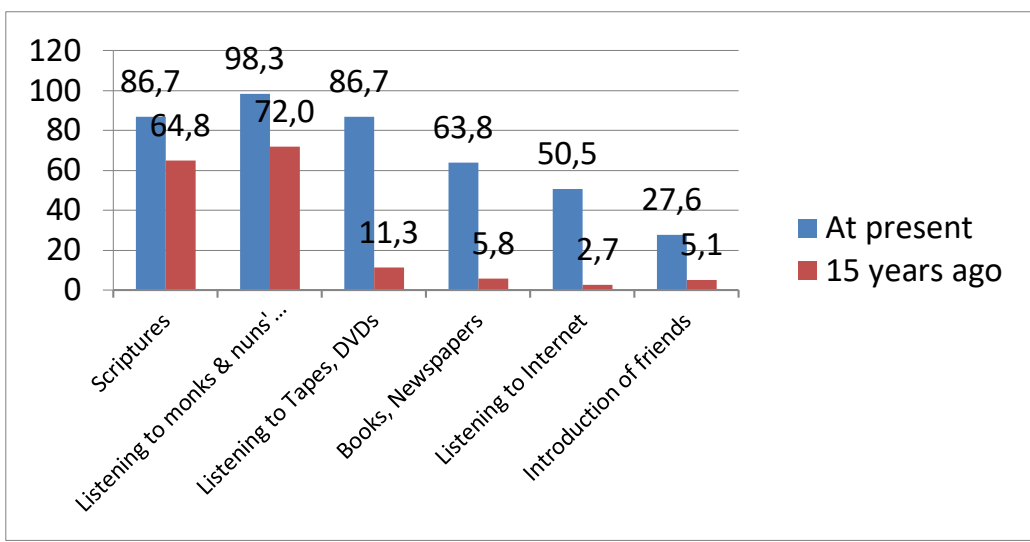

(The results of the field research in Nam Dinh and Thai Binh provinces in July 2017)

In addition, a question of interest is what kinds of doctrine are most recited by Buddhists? Survey results showed that: $87.4 \%$ of respondents said they often recited the daily Sutra, $74.1 \%$ recited the Amitabha Sutra, $70.0 \%$ recited the Ksitigarbha Sutra, 65.2\% recited the Bhaisajyaguru (Medicine) Sutta, 63.1\% recite the Yulanpen Sutra (the Ullambana Sutra), and $56.0 \%$ of respondents recited the Lotus Sūtra (Saddharma Puṇụarīka Sūtra).

Other doctrines are less recited by respondents, including the Repentance sutra (46.4\%), the Heart Sūtra (Prajñāpāramitāhṛdaya) (44.0\%), the Sūrañgama Sūtra (31.7\%), and the Diamond Sūtra (Vajracchedikā Prajñāpāramitā Sūtra) (30.4\%). It should be noted here that the rate of reciting the aforementioned sutras is much higher in comparison to the past. Specifically, in the past, the rate of reciting the daily Sutra was 25.6\%; the Amitabha Sutra was 21.5\%; the Ksitigarbha Sutra was 17.1\%; the Bhaisajyaguru (Medicine) Sutta was 19.1\%; the Yulanpen Sutra was 19.1\%; the Lotus Sūtra was $18.1 \%$; Repentance Sutra was $11.6 \%$; the Heart Sūtra was $10.6 \%$; the Súrangama Sūtra was $6.1 \%$; the Diamond Sūtra was $5.8 \%$.

The aforementioned data show that Buddhists often recite the Buddhist Sutras for their daily-life needs such as health, (existential) security (the Bhaisajyaguru or Medicine Sutta), liberation/deliverance (the Amitabha Sutra), etc. They rarely recite the sutras with abstract content such as the Sürangama Sūtra, the Diamond Sūtra.

On the other hand, the change in Buddhist faith can be seen in the increase of Buddhist altars set up in lay Buddhists' home. The abbot of Nhue Buddhist temple (My Loc District, Nam Dinh Province) said that 'people are more interested in worshiping the Buddha, about $30 \%$ of Buddhists have Buddhist altars at home. They place the altar for Buddha above the altar for ancestors. Many hang an image of Buddha, sometimes Shakyamuni, in the middle' (According to an interview conducted in July 2017). He stated that there was no altar for Buddha in the house of Buddhists over 15 years ago (The above views of the abbot of Nhue Pagoda also agreed with the opinion of Mr. N.T.C, the Nam Dinh Board of Religious Affairs, who said that a family had mainly an ancestor altar in the past; today, the altar of the Buddha has appeared, and many people have built Buddha statues on the terrace, the balcony). According to the results of the survey, 127 people among 293 Buddhists respondents said that they had the altar for Buddha in their house.

\section{Changes in the practice of rituals}

In addition to the change in the Buddhist faith, research shows that there are changes in the practice of Buddhist rituals in contemporary Vietnam. The changes can be 
observed in the way of practice, the frequency of practice, or the amount of time and money spent on rituals.

According to the results of the sociological survey conducted in the provinces of Nam Dinh and Thai Binh in July 2017, a majority of 293 respondents revealed that the practice of Buddhist rituals had been increased in frequency. A few respondents said that the frequency was reduced, and around $20 \%$ said that there had been changes in the practice of ritual. The increase of activities consists of chanting, reciting the Buddha's teachings, listening to dharma talks, attending the ceremony, studying doctrines, performing rituals for the living's security, and rituals for the liberation of the deceased ancestors' soul, making offerings, etc.

The change of practices is noteworthy because there appear non-Buddhist rituals such as rituals conducted for the living's peace and security, for bringing peace to the souls of the dead, for offering representing star to remove bad luck, and for warding off the bad spirit. Indeed, these rituals belong to folk religion. Many Vietnamese not only come to the pagoda to make prayer to Buddha but also perform rituals for security, health, good business, etc. Recently, these non-Buddhist rituals have become ever popular.

The following tables show the participation, the practice of the rituals, the nonBuddhist ritual with comparison to the past.

Table 1: Rituals at Buddhist temples today

\begin{tabular}{|l|l|l|}
\hline Types of rituals & $\begin{array}{l}\text { Number } \\
\text { respondents }\end{array}$ & Percentage \\
\hline $\begin{array}{l}\text { Ceremony for peace, safety, and } \\
\text { protection (cau an) }\end{array}$ & 286 & $97,6 \%$ \\
\hline $\begin{array}{l}\text { Offering representing star to } \\
\text { remove bad luck (cung sao giai } \\
\text { han) }\end{array}$ & 278 & $94,9 \%$ \\
\hline $\begin{array}{l}\text { Masses to bring peace to the souls } \\
\text { of the dead (cau sieu cho nguoi } \\
\text { than da chet) }\end{array}$ & 280 & $95,6 \%$ \\
\hline $\begin{array}{l}\text { Ceremony to offer the name of an } \\
\text { infant to the temple for blessing } \\
\text { (mua khoan, ban khoan) }\end{array}$ & 250 & $85,3 \%$ \\
\hline $\begin{array}{l}\text { Ceremony to ward off the bad } \\
\text { spirit (cat duyen am) }\end{array}$ & 220 & $65,1 \%$ \\
\hline Organize a Mandala & 182 & $62,1 \%$ \\
\hline
\end{tabular}

(The results of the field research in the provinces of Nam Dinh and Thai Binh in July 2017)

Compared to the participation in these same rituals in 15 years ago.

Table 2: Participation in these rituals in 15 years ago

\begin{tabular}{|l|l|l|}
\hline Rituals organized by the temple & $\begin{array}{l}\text { Number } \\
\text { respondents }\end{array}$ & Percentage \\
\hline $\begin{array}{l}\text { Ceremony for peace, safety, and } \\
\text { protection (cau an) }\end{array}$ & 199 & $67,9 \%$ \\
\hline $\begin{array}{l}\text { Offering representing star to } \\
\text { remove bad luck (cung sao giai } \\
\text { han) }\end{array}$ & 174 & $59,4 \%$ \\
\hline $\begin{array}{l}\text { Masses to bring peace to the souls } \\
\text { of the dead (cau sieu cho nguoi }\end{array}$ & 185 & $63,1 \%$ \\
\hline
\end{tabular}

XLinguae, Volume 13 Issue 3, June 2020, ISSN 1337-8384, ISSN 2453-711X 


\begin{tabular}{|l|l|l|}
\hline than da chet) & & $39,6 \%$ \\
\hline $\begin{array}{l}\text { Ceremony to offer the name of an } \\
\text { infant to the temple for blessing } \\
\text { (mua khoan, ban khoan) }\end{array}$ & 116 & $31,4 \%$ \\
\hline $\begin{array}{l}\text { Ceremony to ward off the bad } \\
\text { spirit (cat duyen am) }\end{array}$ & 92 & $30 \%$ \\
\hline Organize a Mandala & 88 & \\
\hline
\end{tabular}

(The results of the field research in the provinces of Nam Dinh and Thai Binh in July 2017)

As can be seen from the two tables above, most respondents shared with us that they participated in the ceremony organized by Buddhist temples. Participation rates are much higher than 15 years ago. The rise of non-Buddhist services shows that the practice of Buddhism is now much oriented to followers' this-worldly needs and wants.

15 years ago, there were factors that limited the practices of Buddhists, such as the lack of time, the lack of resources, the lack of places for worship Buddha, strict law and policy, low income, etc. Nowadays, Buddhist temples have been renovated to be ever spacious. Meanwhile, renovation in policies and laws on religion has created more freedom and favorable conditions for practices of Buddhism. These are the reasons for the increase in the number of Buddhists as well as in their more participation in Buddhist communities' internal affairs and external activities for social welfare.

In addition, the change in the practices of Buddhism can also be observed in the efforts to modernize practices of Buddhism. The achievements of science and technology, the development of the Internet, and the industrial revolution 4.0 are utilized into the promulgation of Buddhist doctrines and the promotion of Buddhist social activities. In Vietnam, there appear "virtual" or "online Buddhist temples," where internet users can perform rituals when they do not have time to attend a real temple. The Buddhist texts, scriptures have been digitized and can be downloaded to mobile phones, computers, tablets, etc. for the purpose of studying and self-teaching. The trend of Buddhist modernization is indispensable in the contemporary social context and will be developed in the future.

One of the interesting changes in Buddhism is the deification of some key events in the life cycle. This trend seems to be contrary to the secularization and modernization of Buddhism. Through observation, the author has found that recently more people choose to organize their wedding ceremony at a Buddhist temple. It can be said that people would expect their wedding to be "sacralized" so it will be durable and full of happiness.

\section{Changes in the Organization of the Buddhist Community}

The Buddhist community analyzed in this article are groups and/or associations of Buddhists based on schools, unique ways of practice doctrine and ritual, as well as age and profession. Analyses of the changes in the organization of the Buddhist community will help to identify a vivid, rich, and diverse picture of the current Buddhist transformation in Vietnam.

One of the most prominent features of the Buddhist community is the strong development of lay-Buddhist groups organized for the practice of Buddhism (Dao trang). At present, there are a large number of Dao trang that practice the Pure Land Buddhism. It should be noted here that some Dao trang do not adhere to any Buddhist temple or under a monk or nun's leadership. These self-organized groups perform self-cultivation according to the knowledge of Buddhism they perceive from books and online sources of doctrines. 
Dao trang are being organized more and more professionally. For example, Dao trang Tân Bảo Buddhist Temple, Lao Cai Province, is organized with the main body and the subordinate units. The administrative council has 01 director general, 01 deputy director, commissioners (in charge of sub-units), departments, clubs. The activities of this Dao trang are organized and implemented. Along with pure-religious activities such as daily chanting, performing rituals, these Dao trang also have social activities. For example, Dao trang Tan Bao Pagoda, Lao Cai, offers meals for patients at the hospital (on Monday, Wednesday, Friday); helps people affected by natural disasters, floods; providing meals for the boarding school; bicycles and scholarships for poor pupils (Notes of the author in an interview with N.T.L, 68 years old, Tan Bao Mandala at Tan Bao pagoda on May 26th, 2017). In the last decade, there appears layBuddhist group to perform chanting to assist the person who is about to decease (Dao trang niem Phat vang sanh). This kind of Buddhist grouping probably first appeared in the South and the Central Highlands (Nam Bo, Tay Nguyen) (According to results of a field trip conducted by the Institute of Research on Religions, Vietnam Academy of Social Sciences in the Central Highlands in July 2013, there was an emergence of Mandala praying for the dead in Dak Lak province. The Executive Council of the Buddhist Sangha of Vietnam in Dak Lak did not support the emergence of the Mandala at that time). Currently, these Buddhist associations can now be found in many provinces and cities of the country.

According to the results survey in Nam Dinh and Thai Binh in July 2017, among the 293 respondents, 264 (accounted for 90,1\%) responded that the number of Dao trang has increased (for the question: whether there are more Dao trang now in comparison with the past).

Table 3: Number of Dao trang

\begin{tabular}{|l|l|l|l|l|}
\hline Answers & Frequency & Percentage & Value & $\begin{array}{l}\text { Accumulated } \\
\text { Percentage }\end{array}$ \\
\hline Increase & 264 & 90.1 & 90.1 & 90.1 \\
\hline $\begin{array}{l}\text { Do not } \\
\text { know }\end{array}$ & 29 & 9.9 & 9.9 & 100.0 \\
\hline Total & 293 & 100.0 & 100.0 & \\
\hline
\end{tabular}

(The results of the field research in the provinces of Nam Dinh and Thai Binh in July 2017)

The emergence of many Dao trang or groups of followers of the Pure Land Buddhism has shown the conversion of the Buddhists. The phenomenon of Buddhists converted from one Dao trang to another, from this branch to another branch, is not rare. The rapid development of the Dao trang of Pure Land Buddhism shows that the faith in Amitabha Buddha is strongly developing. Recently, besides Pure Land Buddhism, there have been new Buddhist communities established in the style of Tibetan Buddhism.

Another feature to mention in terms of the Buddhist community in Vietnam today is the formation of Buddhist communities with a gender structure, age groups, and professional groups. These are open Buddhist communities, without structure organized closely like other Buddhist communities, which are formed on the basis of similarities of age, sex, or needs. For example, summer cultivated sessions for adolescents, teaching courses for different objects or associations. These are the types of Buddhist communities that have been developed in recent years. 


\section{Conclusion}

The article has indicated some major changing trends in Buddhism in Vietnam in comparison to 15 years ago. The change in faith has led to changes in practice and community. Regarding faith, the changes in faith in Buddhism not only reflect the conversion into Buddhism or vice versa; they also indicate the conversion of belief from one branch to another. Regarding practice, pure Buddhist activities do not change much, but the ways of practice have changed significantly. Meanwhile, there is a dramatic increase in social activities performed by Buddhists in frequency, scope, and level.

The aforementioned changes in faith, practices, and community have shown some prominent trends in contemporary Vietnam Buddhism, such as conversion and modernization, individualization of the Buddhist faith, deification, and diversification. These are clearly important features to be aware of when one carries out research projects on Buddhism. They also provide much needed resource and advice to policymakers pertaining to topics related to religion.

When it comes to a philosophical assessment of these trends, there seems to be a tension between traditional thought and modern worldview outlook. (Verchery, 2019) Perhaps the most telling example of such tension is the question of freedom of the human self-determining subject. Modern philosophical schools tend to stress the importance of freedom and self-determination for the human individual. (Pradhan, 2019) Buddha, on the other hand, spoke of predetermined circumstances of one's life based on a given karma. There seems to be a tendency for passivity following from this perspective. Of course, the emphasis of Buddhism on the need on inner enlightenment is well received and incorporated in various models of self-help philosophies and pop-psychology. Moreover, one needs to notice the tendency among modern scholars to perceive Buddhism primarily through the prism of its 'soteriological aims,' which are then immediately presented as incompatible with the analytic philosophical method. A different kind of criticism points out that Buddhism cannot be adapted as a philosophy to the needs and methods of analytical enterprise. These critics incorrectly assume that "Asian cultures advocate the attainment of spiritual ends by abandoning reason." (Siderits, 2016: xiv) They reveal the existence of the prejudice on the side of most of the modern academics, according to which there is an unbridgeable dichotomy between reason and faith in Buddhism. This view, however, is not only false; it is also unfortunate, as it "stands in the way of a potentially fruitful conversation between historically distinct traditions." (Siderits, 2016: xiv)

Buddhist thought is complemented with Confucian ideas and customs, especially among the educated, though this is not to say that Buddhism is reserved for the uneducated. The existing (diverse) trends in Buddhism constitute together with the Confucian philosophical heritage a strong moral substrate for the population. (Nguyen - Le, 2019) It is now the task of both teachers and officials to draw wisely from this fountain of knowledge and use it appropriately to Vietnam's current situation. Buddhist self-examination and meditation has the potential to help cultivating one's personality and moral character (Truong, 2019) and help in achieving a higher level of human development in Vietnam (Truong, 2020).

\section{Bibliographic references}

CHADWIN, J. 2020. Overt and Covert Buddhism: The Two Faces of UniversityBased Buddhism in Beijing. In: Religions, vol. 11, n. 3, n. 131.

CHU, V.T. 2015. Transformation of religions in Vietnam in the context of international integration. In: Religious Studies Review, vol. 17, n.1, pp. 30-39.

CHU, V.T. 2017. Results of quantitative survey conducted in Nam Dinh, Thai Binh in July 2017. Unpublished material of the author. 
HOANG, V.C. 2019. The double-layered of diversification of religion in Postrenovation Vietnam. In: Jorn Borup et. al. (eds), Religious diversity in Asia, Brill.

INSTITUTE FOR RELIGIOUS STUDIES. 2017. Proceedings of the Conference: Religious Changes and Trends in the Centre of Vietnam: Policy Planning, Nha Trang, June 2017. Hanoi: Institute for Religious Studies \& Khanh Hoa Board of Religious Affairs.

INSTITUTE FOR RELIGIOUS STUDIES. 2013. Conference Proceedings: Religious Change in the Central Highlands: Current Situation, Policies and Solutions, Buon Ma Thuot, in July. Hanoi: Institute for Religious Studies \& the Central Highlands Steering Committee.

LE, H.L. - NGUYEN T.P.C. (eds). 2008. Transformation of Religions, Beliefs in Vietnam at Present. Hanoi: World Publishing house.

MALARNEY, Shaun. 2002. Culture, Ritual and Revolution in Vietnam, London and Honolulu: Routledge Curzon and University of Hawaii Press.

NGUYEN, Q.H. - KOSARENKO, N.N. - KHAIRULLINA, E.R. - POPOVA, O.V. 2019. The Relationship between the State and the Catholic Church in Postcolonial Vietnam: The Case of Christian Village of Phung Khoang. In: Bogoslovni Vestnik, vol. 79, n. 2, pp. 521-533.

NGUYEN, Q.T. and Chu, V.T. 2014. Transformation of religions and beliefs in the context of Vietnam's international integration. Research Projects of Vass.

NGUYEN, T.T. - LE, C.S. 2019. Nguyen Trai's thought on philosophical ethics and its value for the Vietnamese society today. In: XLinguae, vol. 12, n. 1, pp. 125-138. ISSN 1337-8384.

NGUYEN, V.D. 2017. Ve su gia tang so nguoi vo than o cac nuoc Bac Au [Regarding the increase in atheists in the Nordic Countries]. Available online: http://btgcp.gov.vn/Plus.aspx/vi/News/38/0/240/0/9860/Ve_su_gia_tang_so_nguoi_vo _than_o_cac_nuoc_Bac_Au

PHAM, Q.P. 2009. Hero and Deity: Tran Hung Dao and the Resurgence of popular religion in Vietnam, Mekong Press.

PHAM, Q.P. 2015. Identifying Changing Trends in Contemporary Religious Life in the Central Highlands. In: Religious Studies Review, vol. 17, n. 2, pp. 3-18.

PHAM, T.D. - Le, N.H. 2008. Sociology, Hanoi: World Publishing House.

PRADHAN, R.C. 2019. Mind, Meaning and World: A Transcendental Perspective. Springer.

SIDERITS, M. 2016. Personal identity and Buddhist philosophy: Empty persons. Londong - New York: Routledge.

TAYLOR, P. 2004. Goddesses on the rise: Pilgrimage and Popular Religion in Vietnam, University of Hawaii press.

TAYLOR, P. 2007. Introduction, in: Philip Taylor (ed), Modernity and Religious Reenchantment in Post-Revolutionary Vietnam, ISEAS publishing.

TRAN, H.H. 2017. "The Conversion of a part of the Khmers in the Southwest of Vietnam". In: Religious Studies Review, vol. 19, n. 3\&4, pp.98-107.

TRUONG, T.T.Q. 2019. The Importance of Personality in the Context of Human Education: Global Experience and Vietnamese Philosophical Perspectives. In: XLinguae, vol. 12, n. 4, pp. 192-211.

TRUONG, T.T.Q. 2020. A Philosophical Assessment of Human Development Approaches and the Vietnamese Experience. In: European Journal of Science and Theology, vol. 16, n. 2, pp. 47-59.

VERCHERY, L. 2019. Both Like and Unlike: Rebirth, Olfaction, and the Transspecies Imagination in Modern Chinese Buddhism. In: Religions, vol. 10, n. 6, p. 364. 
Words: 5293

Characters: 34140 (18,97 standard pages)

Assoc. Prof. Ph.D. Tuan Van Chu

Institute for Religious Studies

Vietnam Academy of Social Sciences

27, Tran Xuan Soan Street

Hai Ba Trung, Hanoi, 100.000

Vietnam

chuvantuan0207@gmail.com 